\title{
Nutrient gradients in Panamanian estuaries: effects of watershed deforestation, rainfall, upwelling, and within-estuary transformations
}

\author{
Ivan Valiela ${ }^{1, *}$, Anne Giblin ${ }^{1}$, Coralie Barth-Jensen ${ }^{1}$, Carolynn Harris ${ }^{1}$, \\ Thomas Stone ${ }^{2}$, Sophia Fox ${ }^{3}$, John Crusius ${ }^{4}$ \\ ${ }^{1}$ The Ecosystems Center, Marine Biological Laboratory, Woods Hole, Massachusetts 02543, USA \\ ${ }^{2}$ Woods Hole Research Center, Falmouth, Massachusetts 02540, USA \\ ${ }^{3}$ Cape Cod National Seashore, National Park Service, Wellfleet, Massachusetts 02667, USA \\ ${ }^{4}$ US Geological Survey, University of Washington, Seattle, Washington 98195, USA
}

\begin{abstract}
To test whether deforestation of tropical forests alters coupling of watersheds, estuaries, and coastal waters, we measured nutrients in 8 watershed-estuarine systems on the Pacific coast of Panama where watershed forest cover ranged from 23 to $92 \%$. Watersheds with greater forest cover discharged larger dissolved inorganic nitrogen concentrations and higher N/P into estuary headwaters. As freshwater mixed with seawater down-estuary, within-estuary biogeochemical processes erased the imprint of watershed deforestation, increased ammonium, lowered nitrate concentrations, and otherwise altered down-estuary water column composition. As estuarine water left mangrove estuaries, ammonium, nitrate, and phosphate, but not dissolved organic nitrogen, were exported to receiving near-shore waters. Mangrove estuaries in this region thus provide important ecological services, by uncoupling coastal waters from changes in terrestrial land covers, as well as by subsidizing adjoined receiving coastal waters by providing nutrients. The pattern of land-sea coupling and exports was disrupted during La Niña-influenced conditions. In one instance when La Niña conditions led to upwelling of deeper layers, high concentrations of marine-derived ammonium were inserted into estuaries. In another instance, La Niña-associated high rainfall diluted nutrient concentrations within estuaries and lowered salinity regionally, and the fresher upper layer impaired coastal upwelling. Regional rainfall has increased during the last decade. If La Niña rainfall continues to increase, disruptions of current land-estuary-sea couplings may become more frequent, with potentially significant changes in nutrient cycles and ecological services in these coupled ecosystems.
\end{abstract}

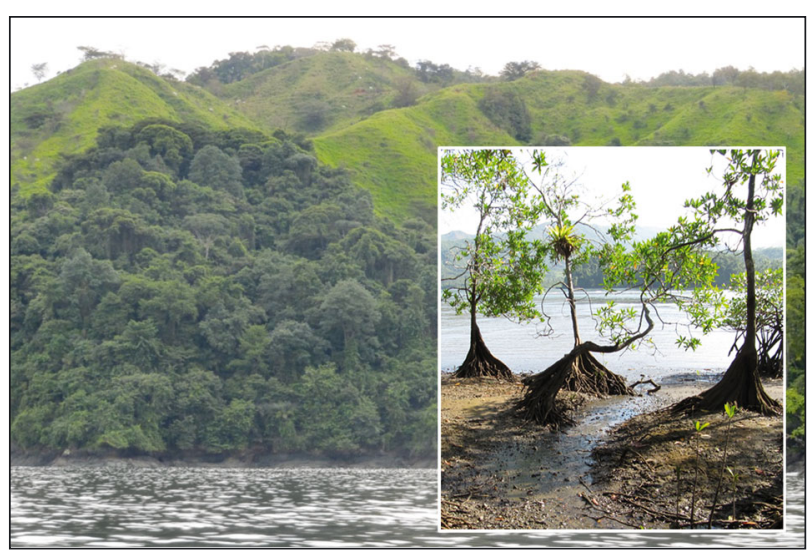

The impacts of anthropogenic changes in land cover on the export of nutrients to tropical estuaries are attenuated by mangroves (inset).

Photos: I. Valiela

KEY WORDS: Mangroves · Deforestation · La Niña · Upwelling $\cdot$ Estuaries $\cdot$ Denitrification $\cdot$ Regeneration · Ecosystem coupling

Resale or republication not permitted without written consent of the publisher

\section{INTRODUCTION}

In terrestrial ecosystems, studies in temperate (Vitousek \& Reiners 1975, Lewis et al. 1999, Lewis 2002, Perakis \& Hedin 2002), and tropical (Williams \& Melack 1997, Williams et al. 1997, Hedin et al. 2003) latitudes discuss the degree to which soils (Jenny 1950), forests (Vitousek \& Howarth 1991, 
Corre et al. 2010), and aquifers process, retain, or release nutrients (Deegan et al. 2011). The coupling of watersheds to receiving waters down-gradient might depend on the identity of nutrient-limiting vegetation on the watershed surface, so that nonlimiting or refractory materials dominate exports (Hedin et al. 2003). Many lowland tropical forests are P-limited (Jenny 1950, Vitousek 1984, Vitousek et al. 1998, Davidson et al. 2007, Brookshire et al. 2011), with rain and $\mathrm{N}$ fixation furnishing $\mathrm{N}$ in excess of internal demand (Martinelli et al. 1999, Cleveland \& Townsend 2006, Davidson et al. 2007). $\mathrm{N}$-limitation may occur in tropical montane forests (Corre et al. 2010, Wullaert et al. 2010), and in recovering stands of lowland forests (Hedin et al. 2003). LeBauer \& Treseder (2008) reported frequent $\mathrm{N}$-limitation in tropical forests from a meta-analysis of fertilization experiments, mostly done in montane and recovering stands. Increased site age may also be associated with $\mathrm{N}-, \mathrm{N}$ and $\mathrm{P}$ co-limitation, and Plimitation of vegetation (Hedin et al. 2003). A longterm fertilization in mature lowland forest in Costa Rica showed that N, P, and $\mathrm{K}$ all played significant roles (Wright et al. 2011). The identity of limiting nutrients in tropical forests may therefore differ from one land parcel to another, and if there is a link between terrestrial nutrient limitation and exports, we can expect a diversity of exports to take place from entire watersheds with a mosaic of different vegetation parcels.

The widespread conversion of tropical forest to other land covers, mainly pastures, should substantially alter downgradient discharges (Davidson et al. 2007, Chaves et al. 2009, Deegan et al. 2011) from watersheds to streams and estuaries (Downing et al. 1999, Borbor-Cordova et al. 2006, Boehm et al. 2010, Uriarte et al. 2011). N uptake and retention in pastures and forests (Downing et al. 1999, Deegan et al. 2011) differed sufficiently such that $\mathrm{N}$ in small tropical streams reflected the mix of surrounding land covers (Saunders et al. 2006, Deegan et al. 2011).

Whatever nutrient imprints emerge from contributing watersheds, we can expect that they will in turn be modified during transit in headwater streams and mangrove estuaries (Harrison et al. 1997, Borbor-Cordova et al. 2006, Saunders et al. 2006, Smith et al. 2011). These withinestuary transformations could further alter potential exports from land to sea
(Dittmar \& Lara 2001a,b, Dittmar et al. 2001, Jennerjahn \& Ittekkot 2002, Mallela \& Harrod 2008). Controls of such concatenated alterations variously depend on many factors, leading Alongi (2009, p. $134)$ to conclude that '[t]here are no universal patterns of dissolved nutrient exchanges between mangroves and adjacent coastal waters.'

This paper has 2 principal aims: to understand the mechanisms that couple adjoining terrestrial, estuarine, and marine ecosystems in a tropical setting, and to discern whether the degree of deforestation on the contributing watersheds modifies that down-gradient coupling.

To investigate the effects of deforestation of tropical lowland forest covers on the coupling to down gradient ecosystems, we identified a series of watersheds on the Pacific coast of Panama (Fig. 1 and see Valiela et al. 2013) among which the degree of deforestation differed, and where the watersheds discharged into adjoined ecosystems, i.e. streams, mangrove estuaries, and coastal waters. Our intention was to use these coupled ecosystems as a readymade landscape-level experiment where we could (1) define down-gradient effects of exports from entire watersheds with different degrees of conversion of mature lowland forest to pastures, and (2) assess how the couplings of these adjoining ecosystems were mediated by nutrient export and transformations.

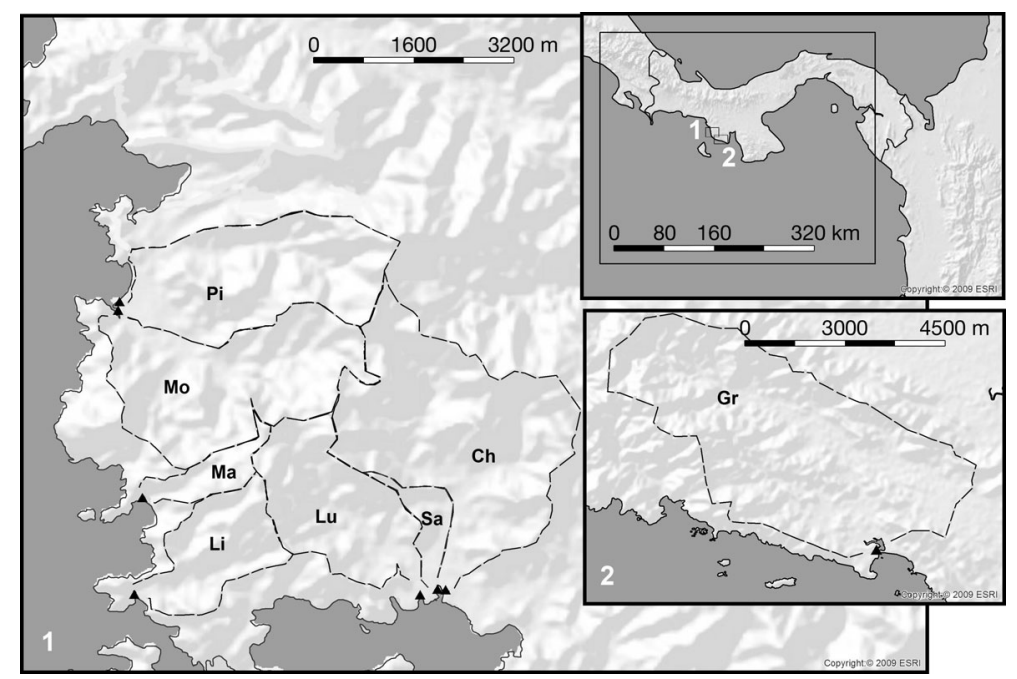

Fig. 1. Study areas. Inset at top right shows Panama-larger box: area used to estimate Tropical Rainfall Measuring Mission regional rainfall; smaller boxes: position of the main areas of our study. Box 1: seven of the watershed-estuary systems (Pi: Rio Pixvae; Mo: Rio de la Mona; Ma: Rio Manglarito; Li: Rio Limon; Lu: Rio Luis; Sa: Rio Salmonete; Ch: Rio Chamuscado). Box 2: Rio Grande (Gr). Watershed delineations are shown with dashed lines; locations of each estuary mouth (Stn 6 in each estuary), sampled from 2009 to 2012, are shown as triangles 
Conversion of lowland wet forest to pastures in this region of Panama occurs by artisan-level felling, burning, and maintenance of small parcels of previously forested land to create pastures for livestock, a pattern common throughout the tropics (Ewel et al. 1981, Kauffman et al. 1995, Chen et al. 2010). The bare soil surface created by burning in this region is short-lived, with grasses growing aggressively on burned parcels within weeks of burning.

To assess couplings, exports, and the effects of different degrees of deforestation, we compared nutrient concentrations discharged from watersheds subject to different degrees of deforestation, followed down-gradient fate of nutrients into headwater streams, during transit within mangrove estuaries, and transport to the near-shore. We assessed changes in nutrient concentrations created by passive mixing or active processes during transit through the gradient from fresh reaches to inlets of the different mangrove estuaries, and evaluated exports from mangrove estuaries to the sea by volume-weighed comparisons of concentrations of nutrients leaving estuaries to concentrations in the surface layer of receiving nearshore marine waters.

During the 3 yr of study (2009 to 2011), 2 fortuitous contingencies - both related to La Niña - took place, creating conditions that allowed us to also assess the degree to which major external drivers could alter the chain of nutrient dynamics. The first unusual condition occurred during the dry season of 2009, when La Niña (www.esrl.noaa.gov/psd/enso/enso. mei_index.html) facilitated a regional upwelling that forced nutrient-laden water into estuaries. This event reversed the usual direction of forcing, and marine imports altered conditions up-estuary. The second event took place during the wet season of 2010, when record La Niña conditions led to higher-than average wet season rainfall (2984 $\mathrm{mm}$ compared to a mean of $2561 \mathrm{~mm}$ for 2004 to 2009, a $17 \%$ increase, from region-wide data from the Tropical Rainfall Measuring Mission, www.trmm.gsfc.nasa.gov/) through northern South America and Central America (Valiela et al. 2012). Local rainfall during the wet season reached considerably larger amounts in the local area of our study (SERVIR, the Mesoamerican Regional Climate Monitoring Center, and authors' pers. obs.). These contrasting climatic settings offered the opportunity to assess global-scale effects on local estuaries and made it possible to examine the additional roles of globally-driven external factorsoccurrence of upwelling and increased rainfall-and how these may interact with effects of deforestation of watersheds and within-estuary transformations.

\section{MATERIALS AND METHODS}

\section{Sites, watershed delineation, and estimation of deforestation on watersheds}

We identified watershed-estuary-near-shore landscape units along the Pacific coast of Veraguas Province, Panama (Fig. 1). The area is characterized by steep slopes, shallow soils, and a complex geology (Castroviejo \& Ibañez 2005). The geologic materials underlying the watersheds included, among other materials, highly spatially heterogeneous and fractured volcanic basalts and diabases, schists and gabbros, and marine and alluvial shales and sandstones (see Fig. S1 in the Supplement at www.int-res.com/ articles/suppl/m482p001_supp.pdf), all affected by extensive metamorphosis and faulting. No one geologic substratum was dominant among the watersheds (Fig. S1).

We acquired digital topographic sheets of the region from the Smithsonian Tropical Research Institute (http://mapserver.stri.si.edu; the maps used were Hoja Topográfica 1:50 k Veraguas Central TLM-50 NB1760 Defense Mapping Agency USA, and Hoja Topográfica 1:50 k Azuero Oeste TLM-50 NB1703 Defense Mapping Agency USA). These maps were imported into our GIS of the region. We then overlaid the digital topographic sheets onto very high resolution QuickBird satellite imagery, and manually digitized watershed boundaries into the GIS.

Each watershed is named after the watercourse (rio) that drains it. The rios are largely springs, fed via base flow maintained by lateral seepage of groundwater, with surface runoff only making a contribution during intense rainstorms. In comparable studies, Williams \& Melack (1997) found that $94 \%$ of Central Amazon wet forest watershed discharge was by base flow. The \% land covers within the watersheds were determined by logging point intercept hits on either forest or pasture, from the crosshairs of a $100 \times 100 \mathrm{~m}$ grid overlaid onto QuickBird false-color imagery. Repeat runs of the procedure on 3 watersheds yielded highly reproducible results.

The region has a strongly seasonal rainfall regime, with a wet season lasting variably from about April to November. Annual rainfall ranges from 2000 to $4000 \mathrm{~mm}$, and has been increasing during the last decade (Valiela et al. 2012). Where forested, the vegetation of the watersheds is seasonal wet forest, with diverse, tall canopies containing trees up to 40-60 m covering steep slopes. Soils are quite shallow, and rainwater seeps quickly into aquifers via extensive jointing present in underlying parent material. 
Human presence in the region is limited. There are 3 small villages, each with populations of 300 to 600 people, and a handful of isolated huts spread through the landscape. There is minimal agriculture in the region. The mangrove forests in the region extend between watersheds and the sea, and include as dominants the neotropically distributed red mangrove Rhizophora mangle and the endemic, geographically restricted piñuelo mangrove Pelliciera rhizophorae. In addition, black Avicennia germinans, white Laguncularia racemosa, and the endemic and threatened marica mangrove Tabebuia palustris are present less abundantly, and there is a diversity of other less common coastal plants.

\section{Water sampling stations}

To define changes in nutrient concentrations in water that just left the watersheds (Fig. 1), entered freshwater streams, moved through estuaries, and out to sea, we took measurements and sampled water at stations upstream, within estuaries, and beyond the mouth of the estuaries. To compare concentrations exported from estuaries to concentrations in surface seawater, we also took measurements and sampled stations farther out to sea.

\section{Sampling in stream-estuaries}

To define water conditions from fresh headwaters to the mouth of each estuary, we sampled water during ebbing tides and measured nutrient concentrations and salinity at 6 stations spaced along a span that captured the fresh- to seawater gradient. During each sampling trip, we changed, to some degree, the specific location of Stns 2 to 5 to make sure the sampling effectively captured the changing gradient in salinity and nutrients created by differences in tidal state and stream flows from one sampling trip to the next. Within-estuary sampling was done at one depth because during ebb tides water columns were mostly shallow $(<1.5 \mathrm{~m})$ and well mixed vertically; some vertical stratification was present, but was spatially highly variable because of uneven bathymetry, fast down-gradient flow (residence time of water within the stream-estuaries is less than $1 \mathrm{~d}$ ), and a large tidal excursion (well over $4 \mathrm{~m}$ for most tides).

To describe conditions as estuary water left the mouth of each estuary and mixed with near-shore water masses, we collected water at 3 more stations, located 50,100, and $300 \mathrm{~m}$ outside the mouth of each estuary, and repeated the procedure followed in the within-estuary stations. In these 3 off-estuary mouth stations, the water column was deeper than within estuaries, so we sampled water at the surface and at depths of $1,2,3,4$, and $5 \mathrm{~m}$.

We sampled each estuary (Stns 1-9) during March 2009, December 2009, March 2010, December 2010, April 2011, and January 2012. This sampling schedule was planned to allow study of the cumulative effects of events during the dry season (which generally occurred from January to April) and the wet season (generally May to December) as well as interannual variation.

\section{Sampling of near-shore waters}

To assess conditions in the marine end-member of the watershed-estuaries, we repeated all measurements and water sampling at 5 stations located between 500 and $1000 \mathrm{~m}$ from shore. Data were taken at the surface and at depths of 10 and $30 \mathrm{~m}$. We sampled near-shore stations during December 2010 and March 2011.

\section{Sampling and analytical procedures}

Salinity was measured in all water samples with a YSI 85-10 unit. Water samples for vertical profiles were collected with a Niskin water sampler. Once obtained, water samples were filtered on site through $0.7 \mu \mathrm{m} \mathrm{GF} / \mathrm{F}$ filters, and frozen until analysis. Nitrate and phosphate were determined by standard colorimetric methods with a Lachat AutoAnalyzer, ammonium was determined by spectrophotometry, and dissolved organic $\mathrm{N}$ (DON) was measured by an initial digestion with persulfate followed by measurement of the resulting nitrate by standard colorimetric methods on a Lachat AutoAnalyzer.

\section{RESULTS}

\section{Watershed deforestation}

The land cover of the watersheds included in this study (Fig. 1) ranged from 23 to $92 \%$ forested (Table 1). This broad span provided a reasonably wide range within which we could assess the effects of conversion of forest to pasture on watershed nutrient export to freshwater streams and estuaries. The gradient in land cover involved was essentially a shift between 
Table 1. Percent land cover in the watershed-estuaries included in this study. Data from Valiela et al. (2012)

\begin{tabular}{|lcc|}
\hline Watershed/ estuary & \multicolumn{2}{c|}{ Land cover (\%) } \\
& Forest & Pasture \\
\hline Pixvae & 73 & 23 \\
De La Mona & 47 & 47 \\
Manglarito & 91 & 6 \\
Limon & 92 & 5 \\
Luis & 73 & 18 \\
Salmonete & 29 & 52 \\
Chamuscado & 66 & 28 \\
Grande & 23 & 43 \\
\hline
\end{tabular}

forest and pastures, since the areas of other types of land cover in the region were small (Valiela et al. 2012). There were minimal areas of recovering forest vegetation, because owners maintained pastures by removal of woody invaders using machetes and selective burning.

\section{Discharge to streams from watersheds}

To define nutrient composition discharged from the different watersheds, we compared concentrations measured in the upper-most stations in the fresh (salinity $<5 \%$ ) reaches of streams. We considered these samples to be representative of recent, mostly lateral, discharge from watersheds (Fig. 2). There were no significant differences in concentrations between samples with 0 and $5 \%$ salinity (see Table S1 in the Supplement).

Watersheds with greater forest cover discharged significantly larger concentrations of nitrate and of dissolved inorganic N (DIN), compared to discharges from watersheds that were deforested (Table 2). Variation in concentrations within the fresh reaches was high, but, on average, watersheds with $>90 \%$ forest cover released as much as twice the amount of DIN compared to discharge from watersheds with

Table 2. Regression equations and p-values comparing nutrient concentrations and \% forest cover in the watersheds for samples from the $<5 \%$ salinity bin from all sampling trips (includes December 2010 and March 2009, southern estuaries). Data shown in Fig. 2. Results for non-significant regressions not shown. DIN: dissolved inorganic nitrogen

\begin{tabular}{|llc|}
\hline Nutrient & Equation & $\mathrm{p}$ \\
\hline $\mathrm{NO}_{3}$ & $y=0.0011 x^{2}-0.0932 x+3.6213$ & $<0.0001$ \\
$\mathrm{DIN}$ & $y=0.0012 x^{2}-0.0994 x+4.4477$ & $<0.0001$ \\
$\mathrm{PO}_{4}$ & $y=0.0002 x^{2}-0.0226 x+0.9908$ & $<0.0001$ \\
\hline
\end{tabular}
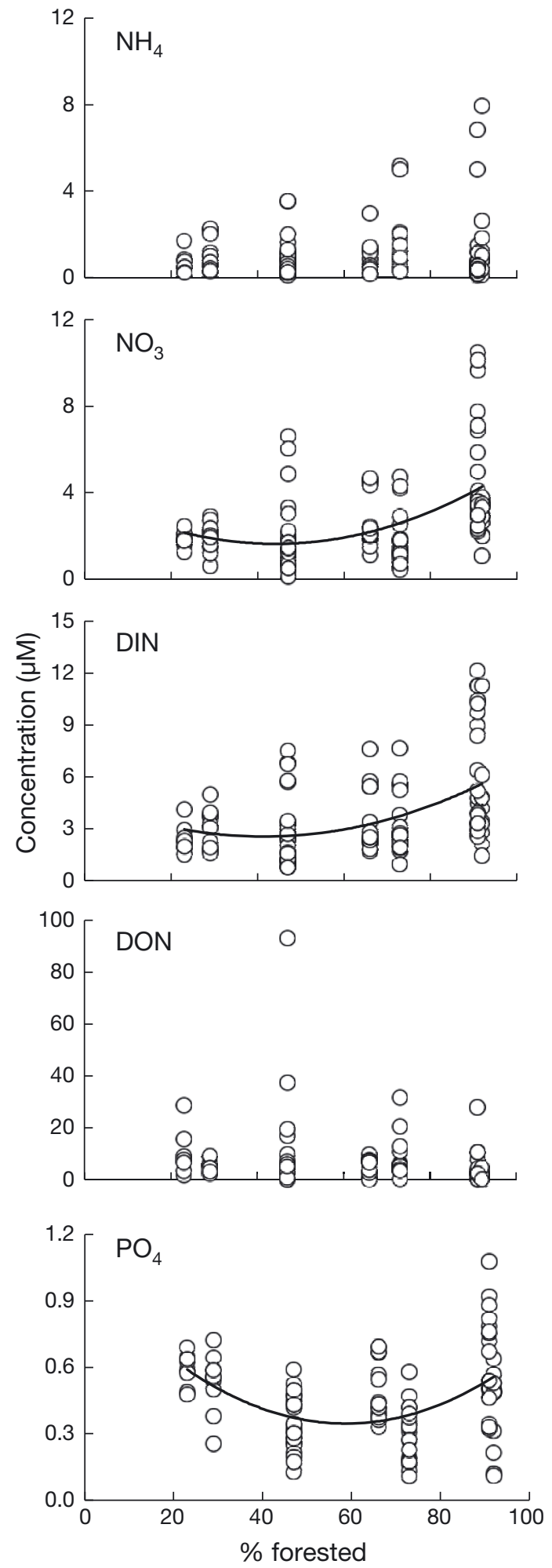

Fig. 2. Concentration of $\mathrm{NH}_{4}, \mathrm{NO}_{3}$, dissolved inorganic and organic nitrogen (DIN and DON), and $\mathrm{PO}_{4}$ vs. \% forest cover in the watershed, for all samples from fresh reaches of estuaries (0-5\% salinity range). Where lines are not shown, regressions were not significant. Regression line statistics are reported in Table 2 
about $20 \%$ forest cover (Fig. 2). There was no relationship between DON concentrations and deforestation of watersheds (Table 2), but concentrations of DON discharged from watersheds reached values higher than those of DIN (Fig. 2), as reported from other tropical sites (Saunders et al. 2006). Phosphate concentrations were low, variable, and were not related to watershed forest cover (Fig. 2, Table 2).

The ratio of $\mathrm{N}$ to $\mathrm{P}$ in freshwater emerging from watersheds and flowing into streams increased significantly in proportion to forest cover (Fig. 3). N/P ratios in waters emerging from the most deforested watersheds were about 4 , and increased in more forested watersheds, but remained below the Redfield value of 16:1 (Fig. 3). These N/P values therefore suggest that growth of producers in the fresh upper reaches of the estuaries was likely $\mathrm{N}$-limited.

\section{Down-estuary erasure of watershed deforestation effects}

The imprint of watershed deforestation on nitrate and DIN concentrations disappeared as freshwater mixed with seawater down-estuary during most sampling events (Fig. 4). Seaward of the fresh reaches, where salinities reached $5-25 \%$ or $>25 \%$, there was substantial variation in nutrient concentrations, with no meaningful pattern of concentration of nutrients among estuaries receiving discharges from watersheds with different forest cover (Fig. 4, Table 3). Some high values in ammonium and nitrate concentrations were measured during sampling in high rainfall and upwelling periods, discussed in the next section.

The loss of watershed-derived nutrient imprints found during most sampling dates was corroborated by N/P values measured in waters with salinity $<5 \%$ compared with N/P values in samples with higher salinity (Fig. 3). The statistically significant relation-

Table 3. Regression equations and p-values for nutrient concentrations vs. \% forest cover in the watersheds, for Stns 1 to 9 during non-eventful years (for data shown in Fig. 4). Results not shown for non-significant regressions. DIN: dissolved inorganic nitrogen

\begin{tabular}{|lccc|}
\hline $\begin{array}{l}\text { Salinity } \\
\text { bin (\%) }\end{array}$ & Nutrient & Equation & $\mathrm{p}$ \\
\hline $5-25$ & $\mathrm{NH}_{4}$ & $y=-0.0015 x^{2}+0.1456 x-0.2731$ & 0.02 \\
& $\mathrm{NO}_{3}$ & $y=-0.0008 x^{2}+0.1098 x-1.3582$ & 0.01 \\
$>25$ & $\mathrm{NO}_{3}$ & $y=-0.0006 x^{2}+0.0698 x-0.7397$ & 0.02 \\
& $\mathrm{DIN}$ & $y=-0.001 x^{2}+0.1022 x-0.1926$ & 0.01 \\
\hline
\end{tabular}

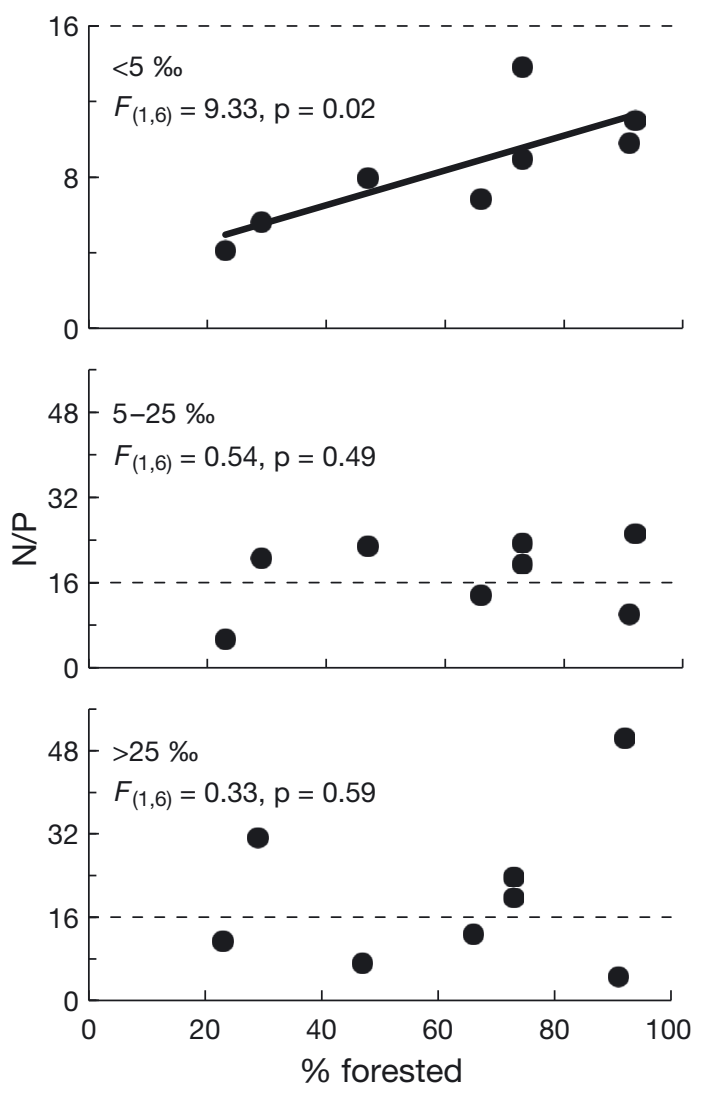

Fig. 3. Mean N/P ratios vs. \% forest cover in the watersheds for 3 salinity ranges: $<5 \%, 5-25 \%$, and $>25 \%$. N/P calculated within each salinity bin, as mean dissolved inorganic nitrogen (DIN) vs. mean $\mathrm{PO}_{4}$ for each estuary. Regression equation in the $<5 \%$ panel is $y=0.0919 x+2.8463$. Where lines are not shown, the regression was not significant. $\mathrm{N} / \mathrm{P}=16: 1$ shown as a dashed line

ship of N/P ratio and \% forested cover that was evident in fresher reaches (Fig. 3) disappeared downestuary (Fig. 3), where within-estuary transformations and mixing apparently gained primacy and altered N/P ratios enough to eliminate the watershed imprint.

\section{Down-estuary nutrient gradients}

The erasure of nutrient imprint of watershed discharge down-estuary (Figs. $3 \& 4$ ) suggested that factors other than watershed inputs governed nutrient concentrations during transit of water through mangrove estuaries. We therefore felt that data from the different estuaries (Figs. S2 to S5 and Table S2 in the Supplement) could be pooled to evaluate patterns of down-estuary changes in nutrient concentrations and to assess the influence of within-estuary processes and seasonal or inter-annual effects. 

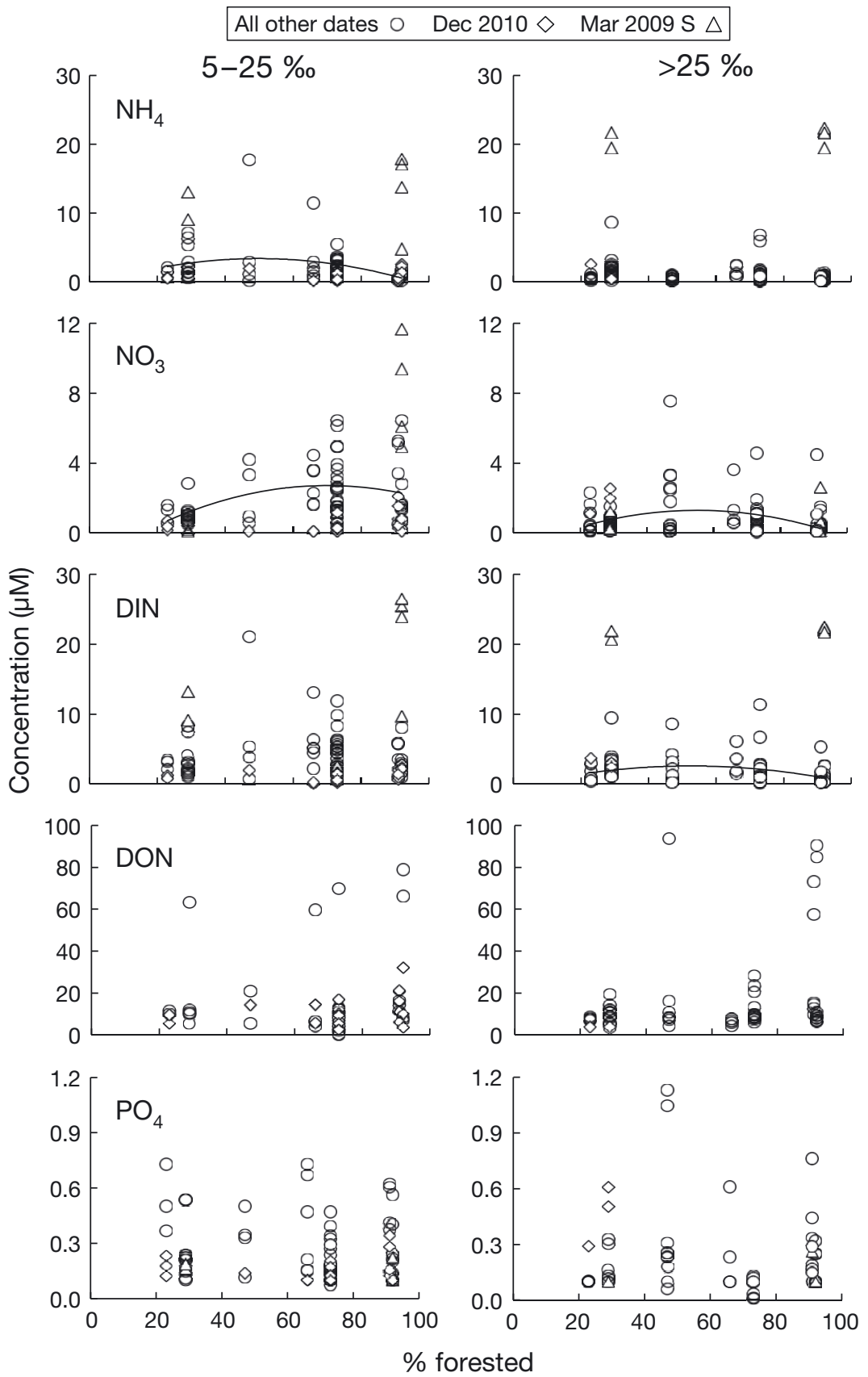

Fig. 4. Concentration of $\mathrm{NH}_{4}, \mathrm{NO}_{3}$, dissolved inorganic and organic nitrogen (DIN and DON), and $\mathrm{PO}_{4}$ vs. \% forest cover in the watersheds for within-estuary samples, stratified into 5-25\% and $>25 \%$ salinity bins. Data for all non-eventful samplings, plus March 2009 data from northern estuaries (Pixvae, de la Mona, and Manglarito) are included in regressions. Data collected in December 2010, and in March 2009 in southern estuaries (Limon, Luis, Salmonete, Chamuscado, Grande), are not included in regression lines. Where lines are not shown, regressions were not significant. Regression line statistics are reported in Table 3

We tested differences between dry and wet seasons and found no significant differences (data not shown). This agrees with results from other tropical streams, for example those of Saunders et al. (2006).
Such smoothing of seasonal signals may be linked to the major role of groundwater-derived base flow, confirmed by ${ }^{222} \mathrm{Rn}$ measurements, in delivery of watershed discharges to these streams and estuaries (J. Crusius et al. unpubl. data). Because of the slow rate of groundwater flow, within-aquifer travel time and lateral delivery throughout the length of streams and estuaries may integrate, and to a degree erase, effects of seasonal inputs. We therefore went on to focus on effects of forest cover, interannual contrasts, and down-estuary changes.

\section{Ammonium}

Ammonium concentrations downestuary, measured during periods that were not affected by La Niña-related weather, were variable, but increased consistently in mid-estuary (Fig. 5, Table 4). The mid-estuary high suggested considerable release of ammonium into the water column, probably by action of ammonium regeneration from mangrove sediments (Mwashote \& Jumba 2002, Ferguson et al. 2004, Alongi et al. 2005, Fernandes et al. 2010, Smith et al. 2011), and perhaps some influence of dissimilatory nitrate reduction to ammonium (Fernandes et al. 2012).

Two La Niña-related features, viz. upwelling during March 2009 and high rainfall during December 2010, affected nutrient concentrations in the estuaries. During March 2009, the gradient in ammonium concentrations sampled from the more southern estuaries (nearer to the Gulf of Panama, an area subject to upwelling; $\mathrm{D}^{\prime} \mathrm{Croz} \&$ O'Dea 2007) suggested inputs of marine-derived ammonium to estuaries (Fig. 5). This upwelling episode took place during a La Niña phase of the El Niño Southern Oscillation that was not associated with increased rainfall. Finding increased ammonium - rather than the more usual nitrate - inside the estuaries borne by up-welled, deeper-layer water 


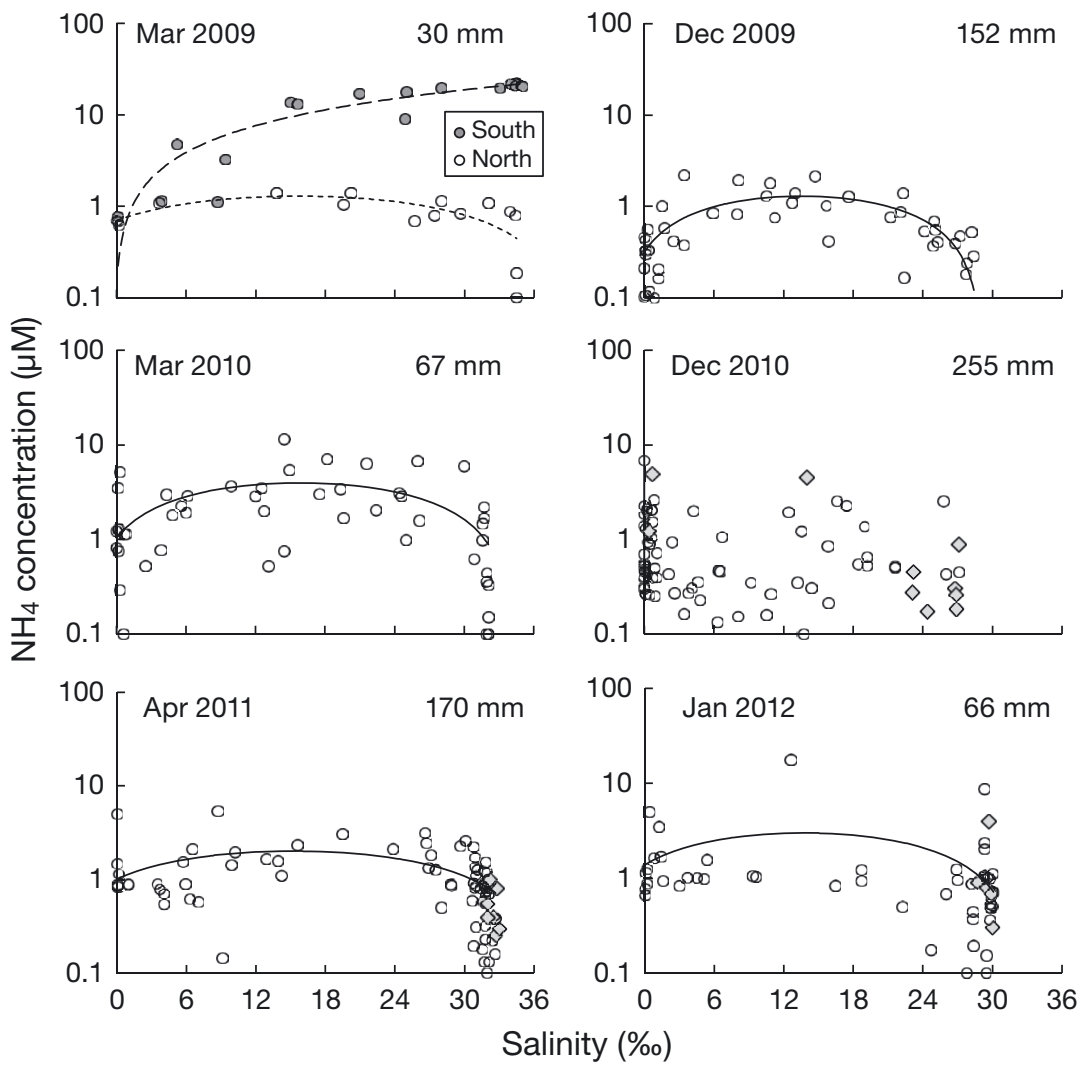

Fig. 5. $\mathrm{NH}_{4}$ concentration vs. salinity for Stns 1 to 9 (circles); for comparison, we added data from near-shore stations (diamonds). Regression lines only include Stn 1 to 9 data. Data from March 2009 split into southern (Limon, Luis, Salmonete, Chamuscado, Grande, and Ballena; the latter is an estuary, not included in Fig. 1, but located SE of Chamuscado, sampled only once during the upwelling event) and northern (Pixvae, de la Mona, and Manglarito) regions. Regression line statistics are reported in Table 4. Here and in Figs. 6 to 8, the numbers at top right of each panel show rainfall during the previous month before sampling

is unusual; in this case, the deeper layer was hypoxic, and hence more likely to hold ammonium (L. Camilli unpubl. data). No upwelling inputs were seen within the more northern estuaries, where, as already mentioned, ammonium concentrations followed the more usual mid-estuary peak (Fig. 5).

During December 2010, the region was affected by La Niña-associated intensification of rainfall that led to a remarkable freshening of estuaries and coastal waters (Valiela et al. 2012). The amount of rain during that wet season was the largest of any of our sampling periods. To convey some idea of the amount of rainfall before our sampling, we inserted the $\mathrm{mm}$ of rain that fell during the month previous to sampling in Fig. 5. The increased freshwater input disrupted the usual down-estuary pattern, significantly reducing salinity, diluting concentrations of ammonium, and creating a modest mid-estuary trough in ammonium concentration (Fig. 5).
Nitrate, DON, and phosphate

Concentrations of nitrate during the December 2009, March 2010, April 2011, and January 2012 samplings decreased nearly linearly down-estuary, apparently following passive dilution with nitrate-poorer seawater (Fig. 6, Table 4; but see discussion of Fig. 9 below). During the upwelling event, concentrations of nitrate increased upstream from the mouth in the southern estuaries, suggesting fast and substantial nitrification of upwelled ammonium (Fig. 6). During December 2010, the intense rainfall diluted nitrate concentrations, forming the mid-estuary trough (Fig. 6) also seen in the ammonium data.

Concentrations of DON within estuarine reaches were higher than any other nutrient, and did not change down-estuary (Fig. 7). The DON might be relatively refractory material, perhaps a remnant of microbial activity and repeatedly transported by hydrodynamic flows back and forth through the estuaries.

Concentrations of phosphate were generally variable and low, tended to decrease down-estuary, unexpectedly did not seem to be affected by upwelling of hypoxic water, but did show the mid-estuary trough during the sampling period exposed to intense rain (Fig. 8, Table 4).

\section{Separation of effects of passive mixing from within-estuary transformations}

To ascertain whether the erasing of watershed imprints was a function of passive dilution during mixing of fresh and seawater end-members, or was attributable to active processes within estuaries, we first calculated passive mixing curves (Officer 1979, Middelburg \& Nieuwenhuize 2001, Dittmar \& Lara $2001 b)$ for each estuary. The freshwater end-member salinity and nutrient concentrations we used were those we measured in stream water with salinity $<1 \%$, which we took to represent recent discharge from the watersheds. For the seawater end-member we used data from near-shore surface water samples 


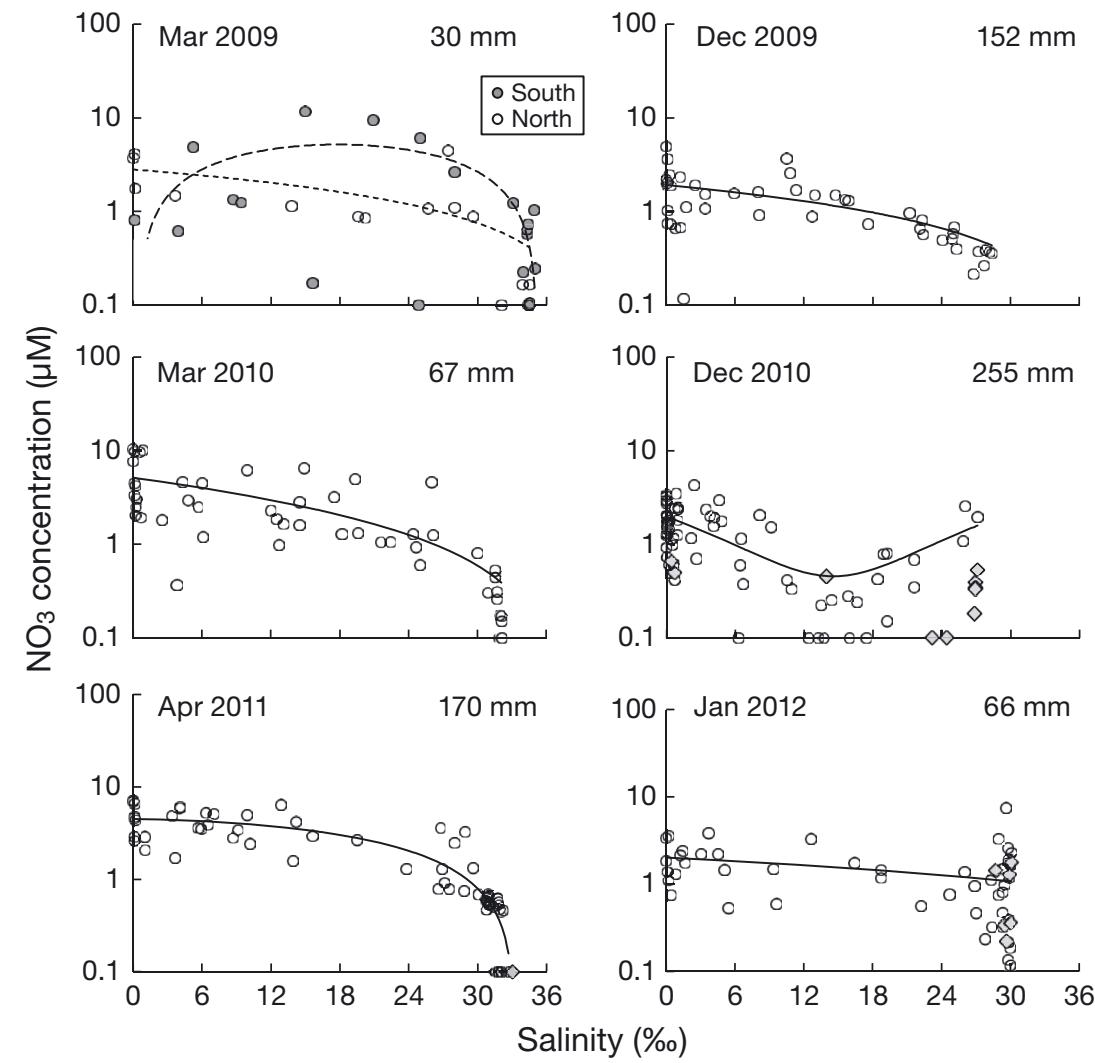

Fig. 6. $\mathrm{NO}_{3}$ concentration vs. salinity for Stns 1 to 9 (circles); for comparison, we added data from near-shore stations (diamonds). Regression lines only include Stn 1 to 9 data. March 2009 panel shows data for southern and northern region separately. Regression line statistics are reported in Table 4

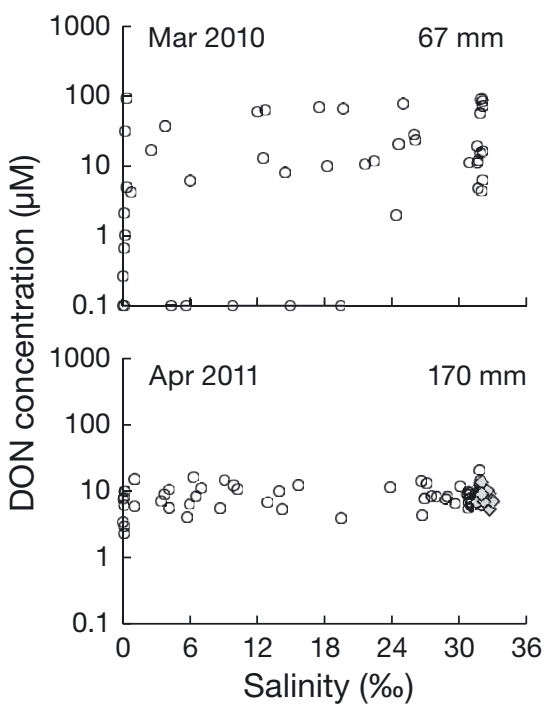

Chiriquí (near where our near-shore stations were located; Fig. 1) reported by $\mathrm{D}^{\prime} \mathrm{Croz} \& \mathrm{O}^{\prime}$ Dea (2007). Then, to assess whether there were actual, within-estuary increases or decreases of concentrations, above or below passive mixing, we calculated deviations of measured nutrient concentration from values set by the passive mixing curves, for each estuary (Fig. S6 in the Supplement). For simplicity of presentation, we pooled estuary-specific deviations from passive mixing into 3 strata of forest cover on the contributing watersheds (23-29, 47-73, or 91-92\% forest cover; Fig. 9).

Deviations from passive mixing calculated for ammonium and nitrate (Fig. 9) suggested (1) no evident differences associated with differences in watershed deforestation, a result confirming the erasure of watershed imprints down-estuary; (2) ammonium concentration deviations increased down-estuary to salinities of about $15 \%$, implying within-estuary insertions (by regeneration or, less likely, by dissimilatory reduction of nitrate to ammonium; Fernandes et al. 2012) during transit down-estuary; (3) deviations in ammonium and nitrate concentrations leaving estuaries seemed largely positive (more points above the dashed line) at salinities $>25 \%$ (Fig. 9), leaving the same visual impression as Figs. 5 to 8 , where concentrations in near-shore waters seem lower than those just leaving the estuaries. In Fig. 9, deviations for nitrate suggested losses, perhaps by denitrification or dissimilatory nitrate reduction to ammonium in the fresher reaches, and some gains (perhaps by nitrification of regenerated ammonium) down-estuary (Fig. 9).

Deviations from passive mixing for DON and phosphate were highly vari-

collected during periods when surface waters were unaffected by either upwelling or excess rain (nutrient concentration data from near-shore surface waters are shown as diamonds in Figs. 5 to 8). The marine end-member values we used were quite similar to results for surface water from the Gulf of able, suggested no differences associated with watershed deforestation, and variably increased during down-estuary transit (Table 3, Fig. 9). Deviations in DON concentrations varied so much, however, as to make interpretation difficult (Fig. 9), in spite of a significant regression (Table 3 ) that suggested a mid- 


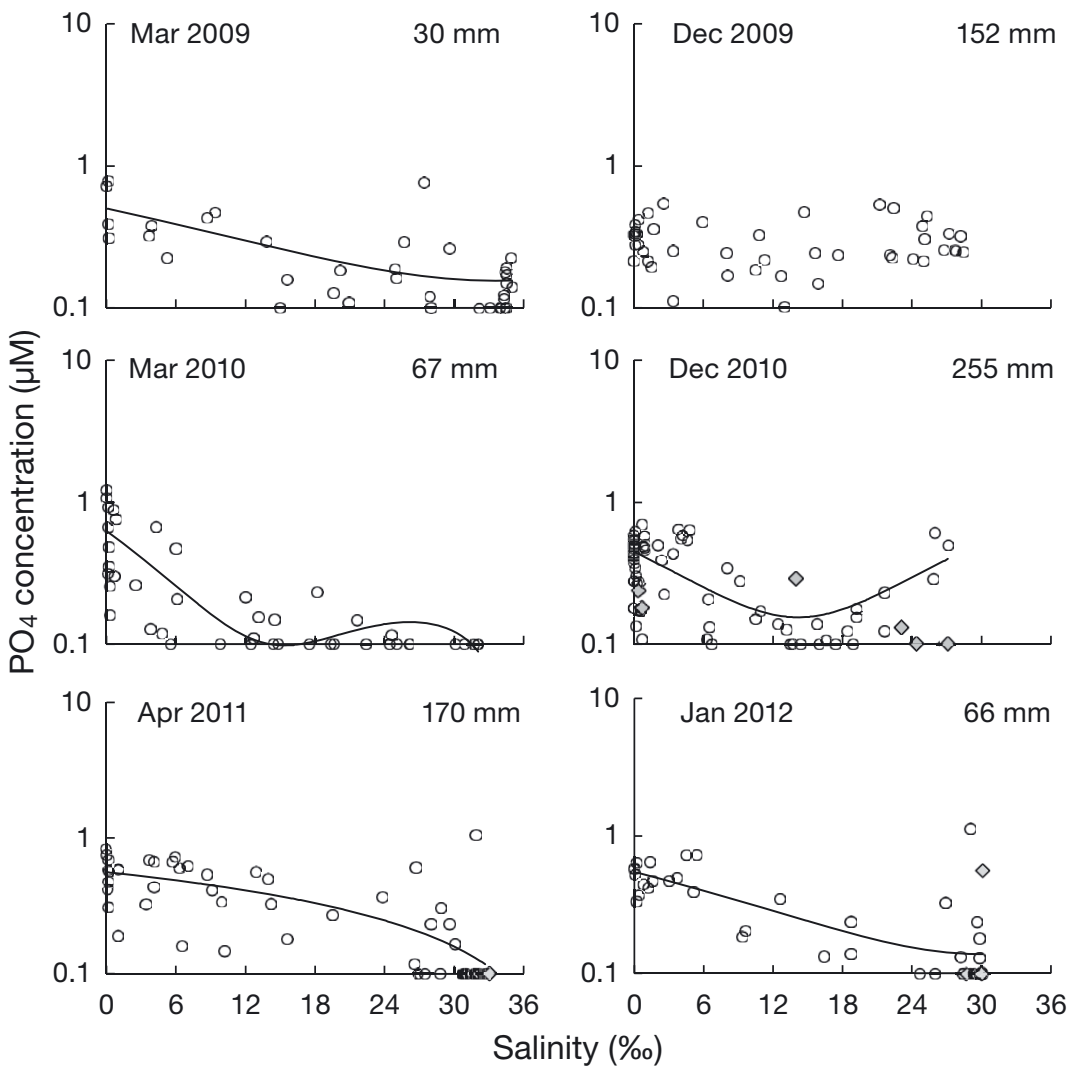

Fig. 8. $\mathrm{PO}_{4}$ concentration vs. salinity for Stns 1 to 9 (circles); for comparison, we added data from near-shore stations (diamonds). Regression lines only include Stn 1 to 9 data. Data in the March 2009 panel were not separated by region because $\mathrm{PO}_{4}$ concentrations in the 2 regions did not differ. Regression line statistics are reported in Table 4 estuary peak. Deviations in phosphate concentrations also varied greatly, and there were no significant trends detectable by regression (Table 3, Fig. 9).

For all nutrients, there were no differences in deviations among dry and wet seasons. The December 2010 high rainfall event did not change the pattern of deviations for any nutrient (Fig. 9).

On the whole, the deviations from passive mixing suggested a propensity for losses of nutrients as watershed-derived water entered fresh reaches, followed by insertions of DIN and DON (but not phosphate) during transit through mid-estuaries. As estuarine water became more mixed with seawater, deviations in DIN and DON decreased, approaching a point that implied convergence toward coastal surface water concentrations.

\section{Exports of nutrients from estuaries}

Actual concentrations (Figs. 5 to 8), and deviations from passive mixing (Fig. 9) suggested differences be-

Table 4. Regression equations and p-values for nutrient concentrations vs. salinity for estuarine (Stns 1 to 9 ) and near-shore samples taken during each sampling trip (for data in Figs. 5, 6 \& 8). Only significant regression lines are shown, except for January $2012 \mathrm{NH}_{4}$, which is included to show that these data follow the same general trend as other years

\begin{tabular}{|c|c|c|c|c|}
\hline Nutrient & Sampling date & Equation & $\mathrm{R}^{2}$ & $\mathrm{p}$ \\
\hline $\mathrm{NH}_{4}$ & $\begin{array}{l}\text { March } 2009 \text { South } \\
\text { March } 2009 \text { North } \\
\text { December } 2009 \\
\text { March } 2010 \\
\text { April } 2011 \\
\text { January } 2012\end{array}$ & $\begin{array}{l}y=-0.0052 x^{2}+0.8261 x-1.0677 \\
y=-0.0024 x^{2}+0.0745 x+0.7024 \\
y=-0.0053 x^{2}+0.1447 x+0.3151 \\
y=-0.0116 x^{2}+0.3686 x+1.0434 \\
y=-0.0043 x^{2}+0.1321 x+1.0105 \\
y=-0.0085 x^{2}+0.2347 x+1.3906\end{array}$ & $\begin{array}{l}0.897 \\
0.544 \\
0.612 \\
0.286 \\
0.162 \\
0.071\end{array}$ & $\begin{array}{c}<0.0001 \\
0.004 \\
<0.0001 \\
0.0002 \\
0.002 \\
0.15\end{array}$ \\
\hline $\mathrm{NO}_{3}$ & $\begin{array}{l}\text { March } 2009 \text { South } \\
\text { March } 2009 \text { North } \\
\text { December } 2009 \\
\text { March } 2010 \\
\text { December } 2010 \\
\text { April } 2011 \\
\text { January } 2012\end{array}$ & $\begin{array}{l}y=-0.0172 x^{2}+0.6119 x-0.2539 \\
y=-0.0002 x^{2}-0.0628 x+2.8081 \\
y=-0.002 x^{2}-0.0004 x+1.7994 \\
y=0.0017 x^{2}-0.2034 x+5.1616 \\
y=0.0072 x^{2}-0.2087 x+1.9754 \\
y=-0.0034 x^{2}-0.0221 x+4.5053 \\
y=-0.0314 x+2.0239\end{array}$ & $\begin{array}{l}0.357 \\
0.417 \\
0.332 \\
0.440 \\
0.344 \\
0.742 \\
0.0859\end{array}$ & $\begin{aligned} & 0.02 \\
& 0.02 \\
& 0.0002 \\
< & 0.0001 \\
< & 0.0001 \\
< & 0.0001 \\
& 0.03\end{aligned}$ \\
\hline $\mathrm{PO}_{4}$ & $\begin{array}{l}\text { March } 2009 \\
\text { March } 2010 \\
\text { December } 2010 \\
\text { April } 2011 \\
\text { January } 2012\end{array}$ & $\begin{array}{l}y=0.0003 x^{2}-0.0206 x+0.5002 \\
y=\left(-7 \times 10^{-5}\right) x^{3}+0.0044 x^{2}-0.0854 x+0.6262 \\
y=0.0015 x^{2}-0.0414 x+0.4477 \\
y=\left(-5 \times 10^{-5}\right) x^{2}-0.0119 x+0.5615 \\
y=0.0005 x^{2}-0.0274 x+0.5465\end{array}$ & $\begin{array}{l}0.425 \\
0.570 \\
0.385 \\
0.520 \\
0.488\end{array}$ & $\begin{array}{l}<0.0001 \\
<0.0001 \\
<0.0001 \\
<0.0001 \\
<0.0001\end{array}$ \\
\hline
\end{tabular}




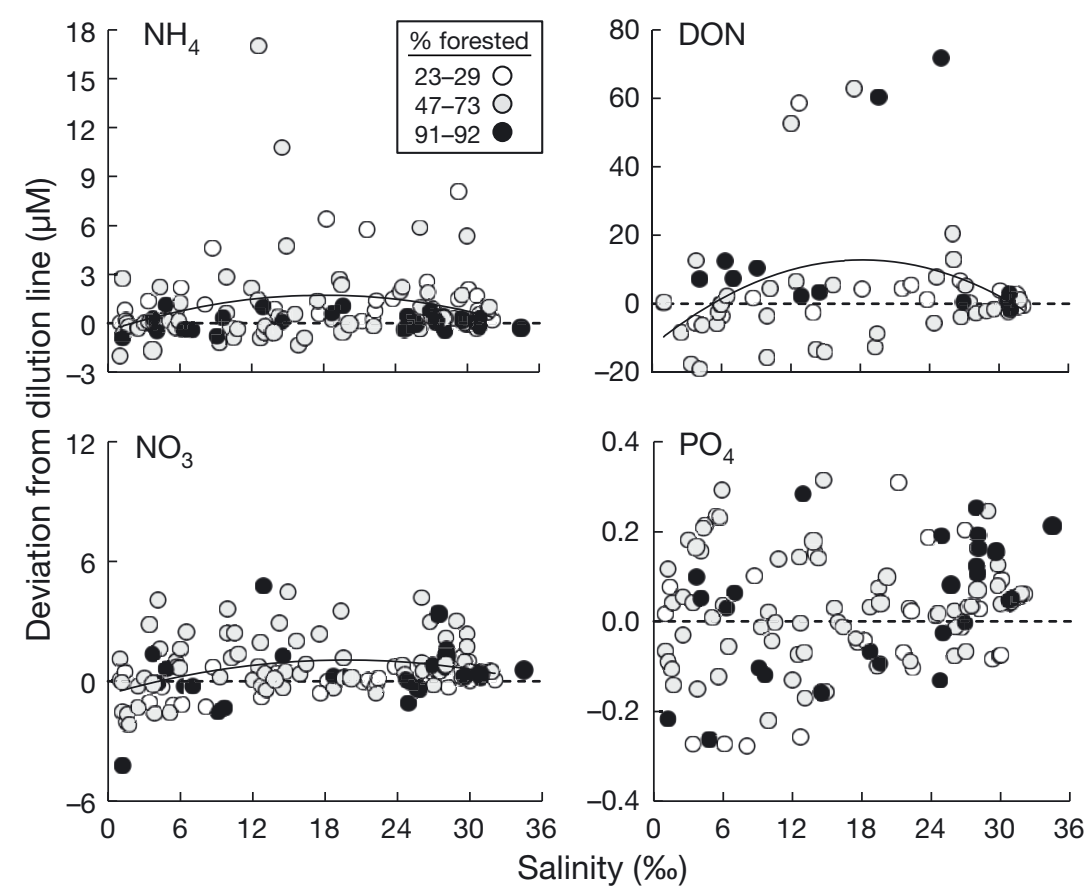

Fig. 9. Deviation of measured concentrations of $\mathrm{NH}_{4}$, dissolved organic nitrogen (DON), $\mathrm{NO}_{3}$, and $\mathrm{PO}_{4}$ relative to passive mixing lines, plotted versus salinity. Data from within-estuary Stns 1 to 6. Data obtained during the La Niña-influenced December 2010, and southern stations sampled during March 2009, are not included in regressions. The dashed line in each panel indicates 0 deviation from the dilution line

tween concentrations leaving estuaries relative to those in receiving coastal waters. To make these comparisons more concrete, we plotted concentrations measured at Stn 6, which was always located at the mouth of each estuary, to concentrations in surface waters near shore (Fig. S7 in the Supplement). The salinity of exiting estuary water differed to some degree from that of near-shore surface water; to compensate for the differences in nutrient concentrations owing to the implied dilution, we normalized estuarine concentrations relative to salinities of near-shore seawater (Broecker \& Peng 1992, Friis et al. 2003) using simple conservation of mass ratios, assuming conservation of salt. Such normalizations provide only approximate corrected concentrations (Robbins 2001), but given the substantial variation we report for all nutrient concentrations (Figs. 4 to 8), the approximations provided adequate, albeit rough, yardsticks. Fig. 10 includes the normalized nutrient concentrations, which suggest several conclusions.

First, there were no discernible differences in concentrations of any nutrient among the watershedestuaries with different degrees of deforestation (grouped, for simplicity in Fig. 10, into estuaries fed by watersheds with $23-29,47-73$, or $91-92 \%$ forest cover). By the time water exited the estuaries, the watershed imprint had dissipated, corroborating the earlier conclusion that, for nutrients, at least in this region of the tropics, watershed-derived nutrient imprints were not transmitted down-estuary.

Second, salinity-normalized concentrations of nitrate and phosphate leaving estuaries were consistently larger than those in the receiving seawater (Fig. 10). This implies that these Panamanian mangrove estuaries export nitrate and phosphate to nutrientdepauperate near-shore waters.

During the La Niña-influenced freshening event of December 2010, estuarine concentrations were strongly diluted (Fig. 5), differences in concentrations were less evident, and concentrations in water leaving estuaries were lower than concentrations in surface near-shore water (blue symbols in Fig. 10), but estuarine flows were greater, and there were salinity dilutions in near-shore surface water (Valiela et al. 2012), so it is hard to speculate as to net effects. To more clearly show the contrasts between water leaving estuaries, and receiving near-shore water, we calculated the ratio of normalized concentrations of nutrients at the estuary mouth, divided by concentrations in near-shore surface water (Fig. 10, Table 5). Although there was variation, mean normalized concentrations of nitrate, ammonium, and phosphate were higher than those in receiving near-shore water in all samplings, except that of December 2010, during the unusually high rainfall season.

\section{DISCUSSION}

The imprint of degree of watershed deforestation was evident in nutrients discharged into fresh reaches of streams: greater forest cover was associated with larger concentrations of DIN measured in fresh stream water. These results agree with meta-data reviews of tropical forests by Downing et al. (1999) and measurements by Deegan et al. (2011) in forest and pasture tracts in the Amazon basin. In contrast, other studies in wet tropical regions (Amazon basin: Williams \& Melack 1997, Williams et al. 1997, Davidson et al. 2007; Hawaii: Boehm et al. 2010) concluded 


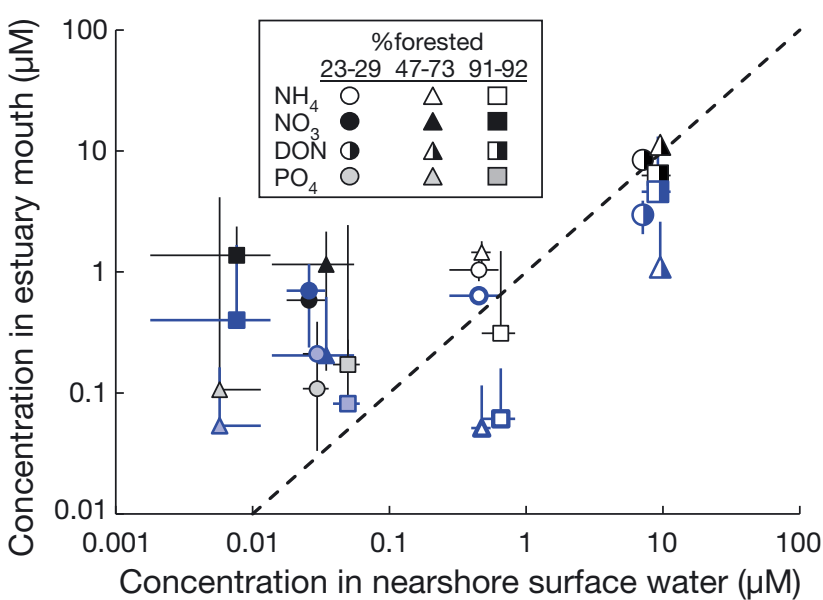

Fig. 10. Comparison of nutrient concentrations at estuary mouths to concentrations (mean $\pm \mathrm{SE}$ ) at near-shore surface waters. December 2010 data are shown as blue points, all other dates are shown as black points. Nutrient concentrations from estuary mouths normalized for salinity differences between samples taken at estuary mouths and the near-shore surface waters. Data from March 2009 southern estuaries are not shown because we had no appropriate marine end-member data for the upwelling event. Dashes indicate 1:1 line

Table 5: Ratios between estuary mouth and near-shore nutrient concentrations (mean \pm SE), for December 2010 sampling and for other sampling dates (data in Fig. 10)

\begin{tabular}{|lccccc|}
\hline \multirow{2}{*}{ Date } & $\mathrm{n}$ & \multicolumn{5}{c|}{ Mouth/nearshore concentration ratio } \\
& & $\mathrm{NO}_{3}$ & $\mathrm{NH}_{4}$ & $\mathrm{DON}$ & $\mathrm{PO}_{4}$ \\
\hline All others & 3 & $87.5 \pm 58.3$ & $2.0 \pm 0.8$ & $1.0 \pm 0.2$ & $6.5 \pm 3.2$ \\
Dec 10 & 3 & $28.4 \pm 13.4$ & $0.5 \pm 0.4$ & $0.3 \pm 0.1$ & $6.0 \pm 2.3$ \\
\hline
\end{tabular}

that deforested watersheds released greater nutrient concentrations than relatively undisturbed forested watersheds.

Our results suggest that first, there are reasonable supplies of available $\mathrm{N}$ moving through tropical forested watersheds (e.g. Hedin et al. 2003, Perring et al. 2008, Brookshire et al. 2011). Second, the pervasive and continuing tropical transition from forest to pastures may lower $\mathrm{N}$ supply to streams, perhaps enough to create $\mathrm{N}$ limitation for aquatic producers. Deforested watersheds in our study discharged low values of N/P (below 16:1), compared to forested watersheds. A similar result was reported for temperate watersheds in Georgia, USA (Houser et al. 2006). These ratios suggest that conversion to pastures could increase $\mathrm{N}$-limitation of producers in receiving streams.

Estimates of N/P ratios discharged from tropical watersheds, however, range widely. Ratios of N/P discharged from our Panamanian watersheds were low (4-14) compared to those measured in other wet tropical sites: 12 to 17 in water emerging from a Peruvian Amazon watershed (Saunders et al. 2006); 12.3 to 20.7 in streams in Hawaii (Boehm et al. 2010); 52 for discharges from tropical forests in general (Loehr 1974); and 170 to 340 in discharge from Amazon watersheds (Williams \& Melack 1997). The land cover in Panamanian watersheds in our study included either forests or pastures; in other cases (Borbor-Cordova et al. 2006, Boehm et al. 2010, Deegan et al. 2011), agricultural, urban, and other land uses were dominant, and bare ground, fertilizer use, and wastewater disposal might create results for nutrient discharges and exports contrary to what we observed. In addition, age of the landscape may affect N/P ratios, as found in a series of forest sites in Hawaii (Hedin et al. 2003), where N/P ranged from $<1$ in younger $\left(<10^{3} \mathrm{yr}\right)$ to $>300$ in older $\left(>10^{4} \mathrm{yr}\right)$ sites. Comparative studies of the effects of watershed deforestation on nutrient export and N/P ratios therefore need to pay attention not only to current land cover, but also to relative age of land cover and geological substrate. Effects of deforestation per se might be better defined within a region with similar vegetation and geology, such as our series of Panamanian watersheds, or the comparisons by Houser et al. (2006).

The erasure of imprint from watershed land covers we report in the remote and unpopulated Panamanian systems contrasts with results from more populated and agricultural watershed-estuary system, where Borbor-Cordova et al. (2006) in Ecuador, Boehm et al. (2010) in Hawaii, and Smith et al. (2011) in northern Australia, reported increased nutrient export from previously forested watersheds. The contrast suggests that different types of land use might indeed lead to different effects on downestuary biogeochemistry. The contrast with our results is not owing to differences in concentrations of nutrients in estuary waters, because the ranges of nitrate and ammonium concentrations in the Hawaiian (1-3.3, 2.2-2.9 $\mu \mathrm{M})$ and Australian (0.07-14.1, $0.15-35.5 \mu \mathrm{M})$ studies overlap with ranges we found in Panama $\left(0-12,0-20 \mu \mathrm{M}_{i}\right.$ Fig. 4). It may be that contrasts in water budgets may be involved; these differences suggest that mass flow rates need to be measured.

The Panamanian mangrove estuaries, in turn, exported DIN (mainly as nitrate) and phosphate to receiving coastal waters off the estuaries, at least under non-La Niña hydrographic regimes. The composition of exported nutrients differed from exports 
of reduced compounds (ammonium and DON) reported for Brazilian mangroves by Dittmar \& Lara (2001b), and for temperate wetlands (Valiela et al. 1978, Valiela \& Teal 1979). Such contrasts in exported materials might mean that exports from estuaries and wetlands have somewhat different effects on coastal food webs, since export of reduced materials are more energy-rich, and may affect heterotrophs rather than producers.

In this paper we depict a set of adjoined ecosystems, and some key linkages. In the absence of La Niña conditions, there were clear couplings of inputs from watersheds with different degrees of deforestation and the fresh upper reaches of streams at the heads of the estuaries. The nutrient signatures confirm the notion that wet tropical forests discharge DIN, and that the conversion of forest to pasture, at least in this region, reduced concentrations of nitrate in streams. Within-stream and estuary biogeochemical transformations soon take over, erase the nutrient imprint received from watersheds, and hence uncouple nutrient cycles in down-estuary ecosystems from direct watershed-specific influences. By the time that mangrove estuary water crosses the mouth of the estuary, and is exported to the near-shore, there is little hint of a specific watershed imprint - the mix of nutrients has changed during transit, and some burial and losses must lower actual transport to the sea. Nonetheless, the mangrove estuaries still manage to export oxidized nutrients to coastal waters in amounts that must be subsidizing coastal food webs.

Global-scale climate shifts have intensified La Niña regimes in the region (Valiela et al. 2012), altering conditions and couplings in the estuaries. When upwelling took place, marine $\mathrm{N}$ sources became dominant, and concentrations of DIN increased in the saltiest reaches of the estuaries. These alterations were geographically restricted to estuaries within the upwelling-susceptible Gulf of Panama region. When a record-high La Niña event was followed by unusually intense rainfall, there were major changes in these environments: nutrient concentrations were diluted, estuary bank erosion and transport of suspended matter increased, and the freshening of surface waters restricted upwelling (Valiela et al. 2012). Although we only have anecdotal evidence (Valiela et al. 2012), these alterations seem substantial enough to inevitably have biological consequences.

Climate-driven shifts such as we report here are not exceptional. There is mounting evidence that global-scale forcing has freshened tropical coastal waters (Durack et al. 2012), and that, at least in Panama, annual precipitation is increasing and can significantly freshen estuarine and coastal waters (Valiela et al. 2012). If these reports are harbingers of future trends, coming conditions might make more common the dilution, freshening, erosion and particle transport, and upwelling impairment, that took place during December 2010, and continued in the wet season of 2011 (Valiela et al. 2012).

The contrasting results reported in the many publications available, and the results we report here, highlight that we are a long way from comprehensive understanding and a synthesis of land-sea coupling in tropical ecosystems. There are, however, more than enough hints that future trends will involve substantial alterations to current functioning of coupled land- and seascapes. The differences in results, and the likely alterations we may be facing, suggest the considerable challenges that await future research.

Acknowledgements. This work was made possible by US NSF grant BIO-0842413. We would not have been able to carry out the fieldwork without the excellent resources of the Liquid Jungle Laboratory (LJL) built by J. Pigozzi, and we are much indebted to the LJL staff for providing excellent support and facilities for our work, and to many friends in the villages of Pixvae, Salmonete, and Bahia Honda for assistance in the field and looking after field recording equipment. We thank L. Madin and the Ocean Life Institute at the Woods Hole Oceanographic Institution for initial support and throughout the work. The support of the Woods Hole Consortium was instrumental to facilitating work by our inter-institutional research team. S. Wilkins, S. Baldwin, J. Pascual, J. Brennan, K. Hernández, R. Monteiro, J. Tucker, R. McHorney, S. Kelsey, N. Mueller, and J. Bissonette helped carry out the demanding field work involved in the project.

\section{LITERATURE CITED}

Alongi AM (2009) The energetics of mangrove forests. Springer, Berlin

Alongi DM, Pfitzner J, Trott LA, Tirendi F, Dixon P, Klumpp DW (2005) Rapid sediment accumulation and microbial mineralization in forests of the mangrove Kandelia candel in the Jiulongjiang Estuary, China. Estuar Coast Shelf Sci 63:605-618

Boehm AB, Yamahara KM, Walters SP, Layton BA and others (2010) Dissolved inorganic nitrogen, solute reactive phosphorus, and microbial pollutant loading from tropical rural watersheds in Hawai'i to the coastal ocean during non-storm conditions. Estuar Coasts 34:925-936

Borbor-Cordova MJ, Boyer EW, McDowell WH, Hall CA (2006) Nitrogen and phosphorus budgets for a tropical watershed impacted by agricultural land use: Guayas, Ecuador. Biogeochemistry 79:135-161

Broecker WS, Peng TH (1992) Interhemispheric transport of carbon dioxide by ocean circulation. Nature 356:587-589

Brookshire ENJ, Gerber S, Webster JR, Vose JM, Swank WT (2011) Direct effects of temperature on forest nitrogen cycling revealed through analysis of long-term watershed records. Glob Change Biol 17:297-308 
Castroviejo S, Ibañez A (2005) Estudios sobre la biodiversidad de la región de Bahía Honda (Veraguas, Panamá). Consejo Superior de Investigaciones Científicas, Madrid

Chaves J, Neill C, Germer S, Gouveia Neto S, Krusche AV, Castellanos Bonilla A, Elsenbeer H (2009) Nitrogen transformations in flowpaths leading from soils to streams in Amazon forest and pasture. Ecosystems 12:961-972

> Chen Y, Randerson JT, van der Werf GR, Morton DC, Mu M, Kasibhatla PS (2010) Nitrogen depositions in tropical forests from savanna and deforestation fires. Glob Change Biol 16:2024-2038

Cleveland CC, Townsend AR (2006) Nutrient additions to a tropical rain forest drive substantial soil carbon dioxide losses to the atmosphere. Proc Natl Acad Sci USA 103: 10316-10321

Corre MD, Veldkamp E, Arnold J, Wright SW (2010) Impact of elevated $\mathrm{N}$ input on soil $\mathrm{N}$ cycling and losses in oldgrowth lowland and montane forests in Panama. Ecology 91:1715-1729

$>$ D'Croz L, O'Dea A (2007) Variability in upwelling along the Pacific shelf of Panama and implications for the distribution of nutrients and chlorophyll. Estuar Coast Shelf Sci 73:325-340

> Davidson EA, Reis de Carvalho CJ, Figueira AM, Ishida FY and others (2007) Recuperation of nitrogen cycling in Amazonian forests following agricultural abandonment. Nature 447:995-998

> Deegan LA, Neill C, Haupert CL, Ballester MVR and others (2011) Amazon deforestation alters small stream structure, nitrogen biogeochemistry and connectivity to larger rivers. Biogeochemistry 105:53-74

$>$ Dittmar T, Lara RJ (2001a) Driving forces behind nutrient and organic matter dynamics in a mangrove tidal creek in North Brazil. Estuar Coast Shelf Sci 52:249-259

> Dittmar T, Lara RJ (2001b) Do mangroves rather than rivers provide nutrients to coastal environments south of the Amazon River? Evidence from long-term flux measurements. Mar Ecol Prog Ser 213:67-77

Dittmar T, Lara RJ, Kattner G (2001) River or mangrove? Tracing major organic matter sources in tropical Brazilian coastal waters. Mar Chem 73:253-271

Downing JA, McClain M, Twilley R, Melack JM and others (1999) The impact of accelerating land-use change on the $\mathrm{N}$-cycle of tropical aquatic ecosystems: current conditions and projected changes. Biogeochemistry 46:109-148

$>$ Durack PJ, Wijffels SE, Matear RJ (2012) Ocean salinities reveal strong global water cycle intensification during 1950 to 2000. Science 336:455-458

Ewel JJ, Berish C, Brown B, Price N, Raich J (1981) Slash and burn impacts on a Costa Rican wet forest site. Ecology 62:816-829

Ferguson AJP, Eyre BD, Gay JM (2004) Nutrient cycling in the sub-tropical Brunswick Estuary, Australia. Estuaries 27:1-17

Fernandes SO, Loka Bharathi PA, Bonin PC, Michotey VD (2010) Denitrification: an important pathway for nitrous oxide production in tropical mangrove sediments (Goa, India). J Environ Qual 39:1507-1516

Fernandes SO, Bonin PC, Michotey VD, Garcia N, Loka Bharathi PA (2012) Nitrogen-limited mangrove ecosystems conserve $\mathrm{N}$ through dissimilatory nitrate reduction to ammonium. Sci Rep 2:419

Friis K, Körtzinger A, Wallace DWR (2003) The salinity normalization of marine inorganic carbon chemistry data. Geophys Res Lett 30:1085, doi:10.1029/2002GL015898
Harrison PJ, Khan N, Yin K, Saleem M and others (1997) Nutrient and phytoplankton dynamics in two mangrove tidal creeks of the Indus River delta, Pakistan. Mar Ecol Prog Ser 157:13-19

- Hedin LO, Vitousek PM, Matson PA (2003) Nutrient losses over four million years of tropical forest development. Ecology 84:2231-2255

Houser JN, Mulholland PJ, Maloney KO (2006) Upland disturbance affects headwater stream nutrients and suspended sediments during baseflow and stormflow. J Environ Qual 35:352-365

Jennerjahn TC, Ittekkot V (2002) Relevance of mangroves for the production and deposition of organic matter along tropical continental margins. Naturwissenschaften 89: $23-30$

Jenny H (1950) Causes of high nitrogen and organic matter content of certain tropical forest soils. Soil Sci 69:63-69

- Kauffman JB, Cummings DL, Ward DE, Babbit R (1995) Fire in the Brazilian Amazon. 1. Biomass, nutrient pools, and losses in slashed primary forests. Oecologia 104:397-408

> LeBauer DS, Treseder KK (2008) Nitrogen limitation of net primary productivity in terrestrial ecosystems is globally distributed. Ecology 89:371-379

Lewis WM Jr (2002) Yield of nitrogen from minimally disturbed watersheds of the United States. Biogeochemistry 57-58:375-385

> Lewis WM Jr, Melack JM, McDowell WH, McClain M, Richey JE (1999) Nitrogen yields from undisturbed watersheds in the Americas. Biogeochemistry 46:149-162

Loehr RC (1974) Characteristics and comparative magnitude of non-point sources. J Water Pollut Control Fed 46: 1849-1872

Mallela J, Harrod C (2008) $\delta^{13} \mathrm{C}$ and $\delta^{15} \mathrm{~N}$ reveal significant differences in the coastal foodwebs of the seas surrounding Trinidad and Tobago. Mar Ecol Prog Ser 368:41-51

Martinelli LA, Piccolo MC, Townsend AR, Vitousek PM and others (1999) Nitrogen stable isotopic composition of leaves and soil: tropical versus temperate forests. Biogeochemistry 46:45-65

- Middelburg JJ, Nieuwenhuize J (2001) Nitrogen isotope tracing of dissolved inorganic nitrogen behaviour in tidal estuaries. Estuar Coast Shelf Sci 53:385-391

Mwashote BM, Jumba IO (2002) Quantitative aspects of inorganic nutrient fluxes in the Gazi Bay (Kenya): implications for coastal ecosystems. Mar Pollut Bull 44: $1194-1205$

> Officer CB (1979) Discussion on the behaviour of nonconservative dissolved constituents in estuaries. Estuar Coast Shelf Sci 9:91-94

> Perakis SS, Hedin LO (2002) Nitrogen loss from unpolluted South American forests mainly via dissolved organic compounds. Nature 415:416-419

Perring MP, Hedin LO, Levin SA, McGroddy M, de Mazancourt C (2008) Increased plant growth from nitrogen addition should conserve phosphorus in terrestrial ecosystems. Proc Natl Acad Sci USA 105:1971-1976

> Robbins PE (2001) Oceanic carbon transport carried by freshwater divergence: Are salinity normalizations useful? J Geophys Res 106:30939-30946

> Saunders TJ, McClain ME, Llerena CA (2006) The biogeochemistry of dissolved nitrogen, phosphorus, and organic carbon along terrestrial-aquatic flowpaths of a montane headwater catchment in the Peruvian Amazon. Hydrol Process 20:2549-2562 
Smith J, Burford MA, Revill AT, Haese RR, Fortune J (2011) Effect of nutrient loading on biogeochemical processes in tropical tidal creeks. Biogeochemistry 108:359-380

Uriarte M, Yackulic CB, Lim Y, Arce-Nazario JA (2011) Influence of land use on water quality in a tropical landscape: a multi-scale analysis. Landscape Ecol 26: 1151-1164

Valiela I, Teal JM (1979) The nitrogen budget of a saltmarsh ecosystem. Nature 280:652-656

Valiela I, Teal JM, Volkmann S, Shafer D, Carpenter EJ (1978) Nutrient and particle fluxes in a salt marsh ecosystem: tidal exchanges and inputs by precipitation and groundwater. Limnol Oceanogr 23:798-812

Valiela I, Camilli L, Stone T, Giblin A and others (2012) Increased rainfall remarkably freshens estuarine and coastal waters on the Pacific coast of Panama: magnitude and likely effects on upwelling and nutrient supply. Global Planet Change 92:130-137

Valiela I, Barth-Jensen C, Stone T, Crusius J, Fox S, Bartholomew M (2013) Deforestation of watersheds of Panama: nutrient retention and export to streams. Biogeochemistry, doi: 10.007/s10533-013-9836-2

Vitousek PM (1984) Litterfall, nutrient cycling, and nutrient limitation in tropical forests. Ecology 65:1476-1490

Editorial responsibility: Jana Davis, Annapolis, Maryland, USA
Vitousek PM, Howarth RW (1991) Nitrogen limitation on land and in the sea: How can it occur? Biogeochemistry 13:87-115

Vitousek PM, Reiners WA (1975) Ecosystem succession and nutrient retention: a hypothesis. Bioscience 25:376-381

Vitousek PM, Hedin LO, Matson PO, Fownes JH, Neff J (1998) Within-system element cycles, input-output budgets, and nutrient limitation. In: Pace ML, Groffman PM (eds) Successes, limitations, and frontiers in ecosystem science. Springer, New York, NY, p 432-451

Williams MR, Melack JM (1997) Solute export from forested and partially deforested catchments in the central Amazon. Biogeochemistry 38:67-102

Williams MR, Fisher TR, Melack JM (1997) Chemical composition and deposition of rain in the central Amazon, Brazil. Atmos Environ 31:207-217

Wright SJ, Yavitt JB, Wurzburger N, Turner BL and others (2011) Potassium, phosphorus, or nitrogen limit root allocation, tree growth, or litter production in a lowland tropical forest. Ecology 92:1616-1625

Wullaert H, Homeier J, Valarezo C, Wilcke W (2010) Response of the $\mathrm{N}$ and $\mathrm{P}$ cycles of an old-growth montane forest in Ecuador to experimental low-level $\mathrm{N}$ and $\mathrm{P}$ amendments. Forest Ecol Manag 260:1434-1445

Submitted: October 5, 2012; Accepted: March 28, 2013 Proofs received from author(s): May 3, 2013 